Original Article

\title{
Expression and Bioinformatics Analysis of Taurine-Upregulated Gene 1 (TUG1) in Esophageal Squamous Cell Carcinoma (ESCC) Tissue Samples Collected from Patients in Golestan Province, Northeast of Iran
}

\author{
Yasaman Fateri $^{1 \mathrm{iD}}$, Eisa Jorjani ${ }^{1} \stackrel{1 \mathrm{iD}}{ }$, Abdolvahab Moradi ${ }^{2} \stackrel{\mathrm{iD}}{ }$, Hosein Sabouri ${ }^{3} \stackrel{\mathrm{iD}}{ }$, Halime \\ Rahimnia $^{1} \stackrel{\text { iD }}{ }$, Shabbou Bahramian ${ }^{2} \stackrel{\text { iD }}{ }$, Zahra Roohineghad ${ }^{2}$, Encieh Delshad. ${ }^{2}$ \\ 1. Department of Biology, Gonbad Kavous University, Gonbad Kavous, Iran \\ 2. Golestan Research Center of Gastroenterology and Hepatology, Golestan University of Medical \\ Sciences, Gorgan, Iran \\ 3. Department of Plant Production, Gonbad Kavous University, Gonbad Kavous, Iran \\ Correspondence: Eisa Jorjani, Department of Biology, Gonbad Kavous University, Gonbad Kavous, \\ Iran. \\ Tel.: +98-9111704665 \\ Email: eisa_jorjani@yahoo.com
}

Received December 10, 2020

Accepted December 28, 2020

\begin{abstract}
Background and objectives: Esophageal squamous cell carcinoma (ESCC) is the most widespread type of esophageal cancer. LncRNA TUG1 was first identified in a genomic screening study for the treatment of taurine in retinal cells. This study aimed at analyzing TUG1 expression in ESCC tissues collected from an Iranian population of patients. Bioinformatics study was also conducted for better understanding the function of this lnc-RNA.

Methods: We examined the expression of TUG1 in 31 pairs of ESCC tissues and adjacent noncancerous tissues by qRT-PCR. Bioinformatics analysis was conducted using various databases. Student's t-test was performed using SPSS software (version 16.0) to evaluate the difference in TUG1 expression between ESCC and adjacent non-cancerous tissues.

Results: TUG1 expression level in ESCC tissues was significantly higher than that in the adjacent non-cancerous tissues $(\mathrm{P}=0.04)$.

Conclusion: TUG1 is upregulated in ESCC, which may be related to history of smoking. Keywords: ESCC; EZH2; Gene expression; Long non-coding RNA; TUG1; SUZ12
\end{abstract}

DOI:10.29252/Jcbr..4.4.17 


\section{INTRODUCTION}

After cardiovascular diseases and accidents, cancer is the most common cause of death worldwide (1) .Esophageal cancer (EC) is the sixth main cause of cancerrelated mortality and the eighth most common malignancy in the world $(2,3)$. In spite of many treatments like surgery and chemotherapy, EC has a poor prognosis with a five-year survival rate (4). Histologically, EC is classified into two general types: esophageal squamous cell carcinoma (ESCC) and esophageal adenocarcinoma (4, 5). ESCC is the most widespread type of EC mainly in low- or medium-income countries, such as Iran (4). In the Golestan Province located in the northeastern part of Iran, EC has an age-standardized incidence rate of 43.4 per 100,000 men and 36.3 per 100,000 women (6) .It has been suggested that EC development may be dependent on several risk factors, including genetic susceptibility, poor oral health, hot tea consumption and poor economic and social status (7). In addition, smoking increases the risk of ESCC development by 1.4 fold $(8,9)$.

Long non-coding RNAs (lncRNAs) are molecules of longer than 200 nucleotides that do not encode proteins. These molecules are associated with some cellular progression processes such as parental imprinting, cell proliferation, apoptosis and metastasis via epigenetic modification, chromatin remodeling and sponging miRNAs $(10,11)$. Evidence suggest that lncRNAs are involved in the onset and progression of cancer and can act as a tumor suppressor or an oncogene (12). Recent investigations reveal that there may be a relationship between upregulation of some lncRNAs such as HOTAIR, POU3F3, FOXCUT and MALAT1 and development of ESCC $(13,14)$. Taurine up-regulated 1 (TUG1), a newly discovered lncRNA, with the length of $7.1 \mathrm{~kb}$, was first identified in a genomic screening study for the treatment of taurine in retinal cells (15). TUG1 often associates with polycomb repressive complex 2 (PRC2) to silence target genes.
Based on the reports from LncRNADisease v2.0 database (http://www.rnanut.net/lncrnadisease/), TUG1 has a role in the pathogenesis of diseases such as B-cell lymphoma, malignant glioma, lung squamous cell carcinoma, renal cell carcinoma, ESCC, intrahepatic cholangiocarcinoma and oral squamous cell carcinoma. Moreover, lncRNA TUG1 has been recently found to contribute to tumor progression via regulation of different cellular processes, including migration, invasion, proliferation, differentiation and apoptosis (16). Considering the unknown factors affecting ESCC progression, identifying biomarkers that detect ESCC is of great importance for clinical surveillance and clinical decision making (13).

In a previous study by Yang et al., it has been reported that alcohol drinking and tobacco smoking together significantly enhance the risk of ESCC among Chinese men (9). Pakzad et al. also reported the high incidence rate of EC in less developed countries because of lifestyle habits, smoking, alcohol use and poor nutrition (17). In ESCC, heavy smokers have been proved to have a two-times higher odds of p53 mutation than non-smokers (18) . Dysregulation of TUG1 is probably associated with p53 mutation during ESCC development (5); therefore, TUG1 may be a therapeutic option for ESCC.

In this study, we evaluate overexpression of lncRNA TUG1 in the tumor tissue and adjacent non-cancerous tissue of ESCC patients in the Golestan Province, northeastern Iran. Moreover, we investigated the relationship between the regulation of IncRNA TUG1 and ESCC clinical parameters.

\section{MATERIALS AND METHODS}

Tissue samples

A total of 31 pairs of ESCC and adjacent normal tissues were collected from ESCC patients (15 men and 16 women). The mean 
age of cases was $60.70 \pm 13$ years. Written informed consent was obtained from all patients prior to participation in the study. Quantitative real-time polymerase chain reaction (qRT-PCR)

Total RNA was extracted from the tissues using Trizol reagent (Invitrogen, CA, USA). The quantity and quality of the extracted RNA were evaluated using a spectrophotometer (Picodrop, UK). Complementary DNA (cDNA) was synthesised using PrimeScript ${ }^{\mathrm{TM}}$ RT Reagent Kit (Takara, Shiga, Japan) and DNase I, RNase-free Kit (SinaClon, Iran) to remove additional DNA. Next, qRT-PCR was performed using the SYBR RealQ Plus Master Mix Green (Ampliqon, Denmark) and $2 \mu \mathrm{l}$ of cDNA in an ABI 7300 thermocycler (Applied Biosystems, CA, USA). All the above-mentioned procedures were conducted based on the instructions provided by the manufacturers. The forward and reverse primers used in this study were TUG1 F: 5'-CTGAAGAAAGGCAACATC3', TUG1 R: 5'GTAGGCTACTACAGGATTTG-3, GAPDH F: 5'GAAGGTGAAGGTCGGAGT-3', and GAPDH R: 5'GAAGATGGTGATGGGATTTC-3'. The relative expression of TUG1 was calculated and normalised using the $2-\Delta \Delta \mathrm{Ct}$ method relative to GAPDH, as the internal control. The cycling conditions for the qRT-PCR experiment are listed in table 1.

Table 1. The cycling conditions for the qRT-PCR experiment

\begin{tabular}{|c|c|c|}
\hline Stage & Temperature $\left({ }^{\circ} \mathbf{C}\right)$ & Duration \\
\hline First stage (one cycle) & 95.0 & $15 \mathrm{sec}$ \\
\hline \multirow{3}{*}{ Second stage (40 cycles) } & 95.0 & $15 \mathrm{sec}$ \\
& 59.0 & $45 \mathrm{sec}$ \\
& 72.0 & $40 \mathrm{sec}$ \\
\hline \multirow{3}{*}{ Third stage (one cycle) } & 95.0 & $15 \mathrm{sec}$ \\
& 60.0 & $1 \mathrm{sec}$ \\
& 95.0 & $15 \mathrm{sec}$ \\
\hline
\end{tabular}

Statistical analysis

All statistical analyses were performed using SPSS software (version 16.0). Student's t-test was used to evaluate the difference in TUG1 expression between ESCC and adjacent non-cancerous tissues.

\section{RESULTS}

lncRNA TUG1 expression in ESCC

The relative expression of lncRNA TUG1 was measured by qRT-PCR in 31 pairs of cancerous and adjacent non-cancerous tissues. As shown in figure 1, the expression level of TUG1 in ESCC tissues was significantly higher (3.98-fold) than that in the adjacent non-cancerous tissues $(\mathrm{P}=0.04)$. 


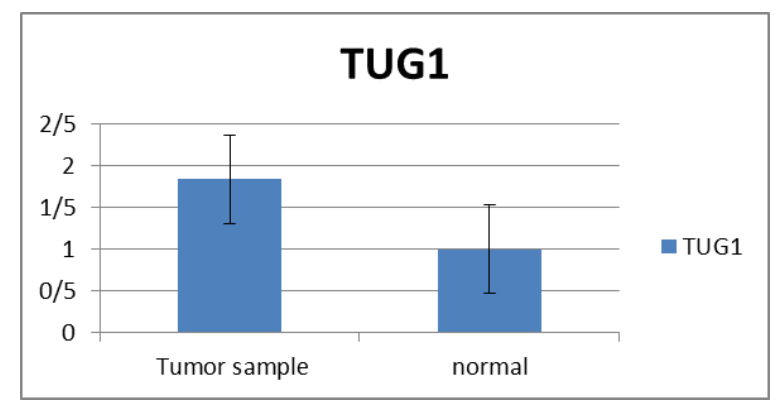

Figure 1. TUG1 relative expression level in ESCC and adjacent non-cancerous tissues

\section{Bioinformatics analysis}

LncRNADisease

(http://www.rnanut.net//ncrnadisease/)

database confirmed the involvement of TUG1 in ESCC. The mutation of these variants resulted in a change in TUG1 expression. Bioinformatics studies also indicated a strong association of EZH2, SUZ12 and HOXB7 with TUG1 products with EC. v2.0 TUG1 expression and clinical parameters By comparing the expression level of TUG1 among clinicopathological parameters, we found a significant relationship between smoking and TUG1 expression level ( $\mathrm{P}=0.038$; Table 2). However, other clinical parameters had no significant correlation with TUG1 expression level. 
Table 2. Clinicopathological factors and the expression of TUG1

\begin{tabular}{|c|c|c|c|}
\hline Variables & $\begin{array}{c}\text { Number of } \\
\text { patients }(\%)\end{array}$ & $\begin{array}{c}\text { Fold } \\
\text { change }\end{array}$ & p-value \\
\hline Age (years) & & & \\
\hline$<50$ & $6(19.35)$ & 1.985815 & \multirow[t]{2}{*}{0.764} \\
\hline$\geq 50$ & 25 (80.64) & 4.460171 & \\
\hline \multicolumn{4}{|l|}{ Sex } \\
\hline Male & $15(48.38)$ & 2.984263 & \multirow[t]{2}{*}{0.105} \\
\hline Female & $16(51.61)$ & 4.915951 & \\
\hline \multicolumn{4}{|l|}{ Histologic grade } \\
\hline $1+2$ & $24(77.41)$ & 3.933252 & \multirow[t]{2}{*}{0.277} \\
\hline $3+4$ & $7(22.58)$ & 4.145873 & \\
\hline \multicolumn{4}{|l|}{ Tumor size } \\
\hline$\leq 5 \mathrm{~mm}$ & $17(54.83)$ & 4.743343 & \multirow{2}{*}{0.937} \\
\hline$>5 \mathrm{~mm}$ & $14(45.16)$ & 3.055881 & \\
\hline \multicolumn{4}{|l|}{ Stage } \\
\hline T1-T2 & $9(29.03)$ & 0.710888 & \multirow[t]{2}{*}{0.141} \\
\hline T3-T4 & $21(67.74)$ & 5.566401 & \\
\hline \multicolumn{4}{|l|}{ Metastasis } \\
\hline $\mathrm{M}_{\mathrm{O}}$ & $15(48.38)$ & 2.000325 & \multirow[t]{2}{*}{0.788} \\
\hline $\mathrm{M}_{1}$ & $9(29.03)$ & 0.727055 & \\
\hline \multicolumn{4}{|l|}{ Smoking } \\
\hline No & $24(77.41)$ & 4.202844 & \multirow[t]{2}{*}{$0.038^{*}$} \\
\hline Yes & $7(22.58)$ & 3.221559 & \\
\hline \multicolumn{4}{|l|}{ Lymph node metastasis } \\
\hline No & $16(51.61)$ & 0.962504 & \multirow[t]{2}{*}{0.155} \\
\hline Yes & $15(48.38)$ & 7.201274 & \\
\hline \multicolumn{4}{|l|}{ Necrosis } \\
\hline No & $17(54.83)$ & 2.138108 & \multirow[t]{2}{*}{0.812} \\
\hline Yes & $14(45.16)$ & 6.21938 & \\
\hline
\end{tabular}




\section{DISCUSSION}

According to recent studies, IncRNAs are critical for many biological processes, such as cellular development and differentiation (19-21). Dysregulation of lncRNA often leads to malignancy (22-24). Jiang et al. reported the upregulation of TUG1 in ESCC tissues, mainly in older cases or chemotherapy-resistant tumors (5). Xu et al. observed TUG1 upregulation in ESCC and suggested a possible involvement in proliferation and migration of ESCC cells (25). Some studies suggested that TUG1 overexpression may also be involved in osteosarcoma (26), human breast cancer (15) and bladder urothelial carcinoma (27). However, Li et al. claimed that TUG1 is downregulated in human glioma tissues, and dysregulation of TUG1 can influence apoptosis and cell proliferation in glioma cells, suggesting that TUG1 may have different roles in various cancers (28). In our study, smoking was significantly associated with upregulation of TUG1 in ESCC samples $(\mathrm{P}=0.038)$. According to Khalil et al., TUG1 is induced by p53 wild type and is able to regulate the cell cycle by connecting to PRC2 (29). They have also indicated that $\mathrm{p} 53$ is the activator and suppressor of a large number of genes, and TUG1 acts as a downstream suppressor in transcriptional pathways. In silico studies have revealed that TUG1, as a competing endogenous RNA, can regulate mRNA expression. Therefore, TUG1 takes a vital part in tumor development and progression through RNA-RNA interactions. Data extracted from the UniProt database (https://www.uniprot.org/) reveals TUG1 interactions with mRNAs and proteins (Table 3). 
Table 3. Data extracted from the UniProt database on the interaction of TUG1 with mRNAs and proteins

\begin{tabular}{|c|c|c|c|}
\hline Gene & Protein & Function & Biological process \\
\hline HOXB7 & $\begin{array}{c}\text { Homeobox protein } \\
\text { Hox-B7 }\end{array}$ & $\begin{array}{c}\text { DNA-binding } \\
\text { transcription factor } \\
\text { activity, proximal } \\
\text { promoter DNA- } \\
\text { binding } \\
\text { transcription } \\
\text { activator activity, } \\
\text { RNA polymerase } \\
\text { II-specific }\end{array}$ & $\begin{array}{l}\text { Embryonic skeletal } \\
\text { system } \\
\text { morphogenesis, } \\
\text { multicellular } \\
\text { organism } \\
\text { development, } \\
\text { regulation of } \\
\text { transcription, DNA- } \\
\text { templated }\end{array}$ \\
\hline EZH2 & $\begin{array}{c}\text { Histone-lysine N- } \\
\text { methyltransferase } \\
\text { EZH2 }\end{array}$ & $\begin{array}{l}\text { Chromatin DNA } \\
\text { binding, DNA- } \\
\text { binding } \\
\text { transcription factor } \\
\text { activity, RNA } \\
\text { polymerase II- } \\
\text { specific, histone } \\
\text { methyltransferase } \\
\text { activity, primary } \\
\text { miRNA binding, }\end{array}$ & $\begin{array}{l}\text { Chromatin } \\
\text { organization, G1 to } \\
\text { G0 transition, } \\
\text { histone methylation, } \\
\text { negative regulation } \\
\text { of gene expression, } \\
\text { epigenetic, positive } \\
\text { regulation of cell } \\
\text { proliferation }\end{array}$ \\
\hline SUZ12 & $\begin{array}{l}\text { Polycomb protein } \\
\text { SUZ12 }\end{array}$ & $\begin{array}{l}\text { Chromatin DNA } \\
\text { binding, } \\
\text { methylated histon } \\
\text { binding, RNA } \\
\text { bindind }\end{array}$ & $\begin{array}{c}\text { Negative regulation } \\
\text { of cell } \\
\text { differentiation, } \\
\text { histone } \\
\text { ubiquitination, } \\
\text { negative regulation } \\
\text { of gene expression, } \\
\text { epigenetic, positive } \\
\text { regulation of cell } \\
\text { proliferation }\end{array}$ \\
\hline MORC2 & $\begin{array}{l}\text { MORC family CW- } \\
\text { type zinc finger } \\
\text { protein } 2\end{array}$ & $\begin{array}{l}\text { Transcriptional } \\
\text { repressor, } \\
\text { cytosolic function } \\
\text { in lipogenesis, } \\
\text { Zinc ion binding }\end{array}$ & $\begin{array}{c}\text { Fatty acid metabolic } \\
\text { process }\end{array}$ \\
\hline SMTN & Smoothelin & $\begin{array}{l}\text { Actin binding, } \\
\text { structural } \\
\text { constituent of } \\
\text { muscle }\end{array}$ & $\begin{array}{l}\text { Actin cytoskeleton } \\
\text { organization, } \\
\text { muscle organ } \\
\text { development, } \\
\text { smooth muscle } \\
\text { contraction }\end{array}$ \\
\hline OSBP2 & $\begin{array}{l}\text { Oxysterol-binding } \\
\text { protein } 2\end{array}$ & $\begin{array}{c}\text { Cholesterol } \\
\text { binding, lipid } \\
\text { binding, sterol } \\
\text { transporter activity }\end{array}$ & $\begin{array}{l}\text { Spermatid } \\
\text { development }\end{array}$ \\
\hline
\end{tabular}


TUG1 may bind to PRC2 and epigenetically regulate gene expression. HOXB7 regulates cell growth, mainly by activating the MAPK and PI3K/AKT pathways, and the destruction of TUG1 can elevate p-ERK, p-AKT and p-GSK3 $\beta$ levels. Regulation of cell growth under TUG1 occurs partly through HOXB7 regulation (30). Chen et al. have also indicated that HOXB7 is one of the HOX genes expressed only in the ESCC tissue and not in normal esophageal mucosa (31) .On the other hand, Huang et al. reported that IncRNA expression can be regulated by some transcription factors such as p53 and SP1 (32). Based on RAID v2.0 database (www.rna-society.org/raid/), TUG1 may interact with EZH2 and SUZ12 proteins. Hence, evaluating of the function and interaction of these proteins with TUG1 in ESCC in future studies can be beneficial for finding novel strategies to control ESCC progression.

In our study, the qRT-PCR analysis showed lncRNA TUG1 overexpression in an Iranian population of ESCC patients. However, further investigations with a larger study population are needed to clarify the exact role of TUG1 in ESCC. In this survey, due to the high cost of testing, the clinical function of TUG1 was evaluated only with qRT-PCR and bioinformatics analysis. More studies are required to understand the exact function of TUG1 in EC and its association with the mentioned proteins.

\section{CONCLUSION}

Our findings reveal that TUG1 is overexpressed in ESCC tissues, which may be associated with history of smoking. Our results also illustrate the importance of lifestyle and epigenetic factors in the development and progression of ESCC. Therefore, TUG1 can be considered as a potential therapeutic target in ESCC. The bioinformatics analysis also revealed a strong association between the proteins EZH2, SUZ12, and HOXB7 and TUG1, which may be associated with EC development .

\section{ACKNOWLEDGMENTS}

We would like to thank Massoud Bazori and Naeme Javid for their helpful comments.

\section{DECLARATIONS \\ Funding}

This study received financial support from the Gonbad Kavous University, Iran.

\section{Ethics approvals and consent to participate}

Written informed consent was obtained from all patients prior to participation in the study.

\section{Conflict of interest}

The author declares that there is no conflict of interest regarding publication of this article.

\section{REFEENCES}

1. Kolahdoozan S, Sadjadi A, Radmard AR, Khademi H. Five Common Cancers in Iran. Archives of Iranian Medicine (AIM). 2010;13(2).

2. Ma K, Cao B, Guo M. The detective, prognostic, and predictive value of DNA methylation in human esophageal squamous cell carcinoma. Clinical epigenetics. 2016;8(1):43. https://doi.org/10.1186/s13148-016-0210-9

3. Ohashi S, Miyamoto Si, Kikuchi O, Goto T, Amanuma Y, Muto M. Recent advances from basic and clinical studies of esophageal squamous cell carcinoma. Gastroenterology. 2015;149(7):1700-15.

https://doi.org/10.1053/j.gastro.2015.08.054

4. Gholipour M, Islami F, Roshandel G, Khoshnia M, Badakhshan A, Moradi A, et al. Esophageal cancer in Golestan Province, Iran: a review of genetic susceptibility and environmental risk factors. Middle East journal of digestive diseases. 2016;8(4):249.

https://doi.org/10.15171/mejdd.2016.34 
5. Jiang L, Wang W, Li G, Sun C, Ren Z, Sheng $\mathrm{H}$, et al. High TUG1 expression is associated with chemotherapy resistance and poor prognosis in esophageal squamous cell carcinoma. Cancer chemotherapy and pharmacology. 2016;78(2):333-9.

https://doi.org/10.1007/s00280-016-3066-y

6. Forghanifard MM, Vahid EE, Dadkhah E, Gholamin M, Noghabi SB, Ghahraman M, et al. Loss of heterozygosity and microsatellite instability as predictive markers among Iranian esophageal cancer patients. Iranian journal of basic medical sciences. 2016;19(7):726.

7. Golalipour G, Semnani S, Safaie B, Rajaie S, Sedaghat S, Kamalinia H, et al. Predictors of survival in oesophageal cancer patients in a high - risk area in Northern Iran: the role of health services utilisation. European journal of cancer care. 2017;26(1).

https://doi.org/10.1111/ecc.12549

8. Chang CM, Corey CG, Rostron BL, Apelberg BJ. Systematic review of cigar smoking and all cause and smoking related mortality. BMC Public Health. 2015;15(1):390. https://doi.org/10.1186/s12889-015-1617-5

9. Yang X, Chen X, Zhuang M, Yuan Z, Nie S, $\mathrm{Lu} \mathrm{M}$, et al. Smoking and alcohol drinking in relation to the risk of esophageal squamous cell carcinoma: A population-based case-control study in China. Scientific reports. 2017;7(1):17249.

https://doi.org/10.1038/s41598-017-17617-2

10. Du Z, Sun T, Hacisuleyman E, Fei T, Wang $\mathrm{X}$, Brown $\mathrm{M}$, et al. Integrative analyses reveal a long noncoding RNA-mediated sponge regulatory network in prostate cancer. Nature communications. 2016;7:10982.

https://doi.org/10.1038/ncomms10982

11. Xu Y, Ge Z, Zhang E, Zuo Q, Huang S, Yang N, et al. The lncRNA TUG1 modulates proliferation in trophoblast cells via epigenetic suppression of RND3. Cell death \& disease. 2017;8(10):e3104.

https://doi.org/10.1038/cddis.2017.503

12. Wang P, Wu Y, Zhong X, Liu B, Qiao G. Prognostic significance of overexpressed long non-coding RNA TUG1 in patients with clear cell renal cell carcinoma. Eur Rev Med Pharmacol Sci. 2017;21(1):82-6.

13. Deng H-Y, Wang Y-C, Ni P-Z, Lin Y-D, Chen L-Q. Long noncoding RNAs are novel potential prognostic biomarkers for esophageal squamous cell carcinoma: an overview. Journal of thoracic disease. 2016;8(8):E653.

https://doi.org/10.21037/jtd.2016.07.01

14. Tang W-W, Wu Q, Li S-Q, Tong Y-S, Liu $\mathrm{Z}-\mathrm{H}$, Yang T-X, et al. Implication of IncRNAs in pathogenesis of esophageal cancer. OncoTargets and therapy. 2015;8:3219. https://doi.org/10.2147/OTT.S87856

15. Li T, Liu Y, Xiao H, Xu G. Long noncoding RNA TUG1 promotes cell proliferation and metastasis in human breast cancer. Breast Cancer. 2017;24(4):535-43.

https://doi.org/10.1007/s12282-016-0736-x

16. Liu J, Lin J, Li Y, Zhang Y, Chen X. Prognostic role of lncRNA TUG1 for cancer outcome: evidence from 840 cancer patients. Oncotarget. 2017;8(30):50051.

https://doi.org/10.18632/oncotarget.17844

17. Pakzad R, Mohammadian-Hafshejani A, Khosravi B, Soltani S, Pakzad I, Mohammadian $\mathrm{M}$, et al. The incidence and mortality of esophageal cancer and their relationship to development in Asia. Annals of translational medicine. 2016;4(2).

https://doi.org/10.1016/j.prnil.2015.09.001

18. McCain RS, McManus DT, McQuaid S, James JA, Salto-Tellez M, Reid NB, et al. Alcohol intake, tobacco smoking, and esophageal adenocarcinoma survival: a molecular pathology epidemiology cohort study. Cancer Causes \& Control. 2020;31(1):1-11. https://doi.org/10.1007/s10552-019-01247-2

19. Schmitz SU, Grote P, Herrmann BG. Mechanisms of long noncoding RNA function in development and disease. Cellular and molecular life sciences. 2016;73(13):2491-509. https://doi.org/10.1007/s00018-016-2174-5

20. Zhang E, He X, Yin D, Han L, Qiu M, Xu $\mathrm{T}$, et al. Increased expression of long noncoding RNA TUG1 predicts a poor prognosis of gastric cancer and regulates cell proliferation by 
epigenetically silencing of p57. Cell death \& disease. 2017;7(2):e2109.

https://doi.org/10.1038/cddis.2015.356

21. Ma P-J, Guan Q-K, Meng L, Qin N, Zhao $\mathrm{J}$, Jin B-Z. Long non-coding RNA TUG1 as a potential prognostic biomarker in human cancers: a meta-analysis. Oncotarget. 2017;8(37):62454.

https://doi.org/10.18632/oncotarget.19099

22. Kong Q, Qiu M. Long noncoding RNA SNHG15 promotes human breast cancer proliferation, migration and invasion by sponging miR-211-3p. Biochemical and biophysical research communications. 2018;495(2):1594-600.

https://doi.org/10.1016/j.bbrc.2017.12.013

23. Khandelwal A, Malhotra A, Jain M, Vasquez KM, Jain A. The emerging role of long non-coding RNA in gallbladder cancer pathogenesis. Biochimie. 2017;132:152-60.

https://doi.org/10.1016/j.biochi.2016.11.007

24. Zhang H, Chen Z, Wang X, Huang Z, He $Z$, Chen Y. Long non-coding RNA: a new player in cancer. Journal of hematology \& oncology. 2013;6(1):37.

https://doi.org/10.1186/1756-8722-6-37

25. Xu Y, Wang J, Qiu M, Xu L, Li M, Jiang $\mathrm{F}$, et al. Upregulation of the long noncoding RNA TUG1 promotes proliferation and migration of esophageal squamous cell carcinoma. Tumor Biology. 2015;36(3):164351.

https://doi.org/10.1007/s13277-014-2763-6

26. Ma B, Li M, Zhang L, Huang M, Lei J-B, Fu G-H, et al. Upregulation of long non-coding RNA TUG1 correlates with poor prognosis and disease status in osteosarcoma. Tumor Biology. 2016;37(4):4445-55.

https://doi.org/10.1007/s13277-015-4301-6
27. Han Y, Liu Y, Gui Y, Cai Z. Long intergenic non-coding RNA TUG1 is overexpressed in urothelial carcinoma of the bladder. Journal of surgical oncology. 2013;107(5):555-9.

https://doi.org/10.1002/jso.23264

28. Li J, Zhang M, An G, Ma Q. LncRNA TUG1 acts as a tumor suppressor in human glioma by promoting cell apoptosis. Experimental Biology and Medicine. 2016;241(6):644-9.

https://doi.org/10.1177/1535370215622708

29. Khalil AM, Guttman M, Huarte M, Garber M, Raj A, Rivea Morales D, et al. Many human large intergenic noncoding RNAs associate with chromatin-modifying complexes and affect gene expression. Proceedings of the National Academy of Sciences of the United States of America. 2009;106(28):11667-72. https://doi.org/10.1073/pnas.0904715106

30. Zhang EB, Yin DD, Sun M, Kong R, Liu $\mathrm{XH}$, You LH, et al. P53-regulated long noncoding RNA TUG1 affects cell proliferation in human non-small cell lung cancer, partly through epigenetically regulating HOXB7 expression. Cell death \& disease. 2014;5(5):e1243.

https://doi.org/10.1038/cddis.2014.201

31. Chen K-N, Gu Z-D, Ke Y, Li J-Y, Shi X-T, $\mathrm{Xu}$ G-W. Expression of $11 \mathrm{HOX}$ genes is deregulated in esophageal squamous cell carcinoma. Clinical Cancer Research. 2005;11(3):1044-9.

32. Huang M-D, Chen W-M, Qi F-Z, Sun M, $\mathrm{Xu}$ T-P, Ma $\mathrm{P}$, et al. Long non-coding RNA TUG1 is up-regulated in hepatocellular carcinoma and promotes cell growth and apoptosis by epigenetically silencing of KLF2. Molecular cancer. 2015;14(1):165.

https://doi.org/10.1186/s12943-015-0431-0

How to Cite: Fateri Y, Jorjani E, Moradi A, Sabouri H, Rahimnia H, Bahramian S, et al . Expression and Bioinformatics Analysis of Taurine-Upregulated Gene 1 (TUG1) in Esophageal Squamous Cell Carcinoma (ESCC) Tissue Samples Collected from Patients in Golestan Province, Northeast of Iran. jcbr. 2020; 4 (4) 